\title{
THE USE OF CODE MIXING ON INSTAGRAM BY THE STUDENTS OF ENGLISH LANGUAGE EDUCATION
}

\author{
Livia Hilda \\ English Language Education, Universitas Pendidikan Ganesha \\ e-mail: liviahilda27@gmail.com \\ Dewa Putu Ramendra \\ English Language Education, Universitas Pendidikan Ganesha \\ e-mail: putu.ramendra@undiksha.ac.id \\ Gede Mahendrayana \\ English Language Education, Universitas Pendidikan Ganesha \\ e-mail: mahendrayana@undiksha.ac.id
}

\begin{abstract}
This study aimed at analyzing the use of code mixing on Instagram by the students of English Language Education Department which covered the types and the reasons of using code mixing. The design of this study was descriptive qualitative study which only focused on describing Indonesian-English code mixing used by ELE students. The participants of this study were the fourth semester students of English Language Education Department at Ganesha University of Education. The data were collected by observing the participants' Instagram account and interviewing the participants through Google Form. The data were analyzed using the combination of some theories. Hoffman, Ho, and Muysken's theories were combined and used to analyze the types of code mixing. Meanwhile, to analyze the reason of using code mixing, Hocket, Hoffman, and Saville-Troike's theories were used. The result showed that most of the participants used intra-sentential type of code mixing with 107 occurrences $(56 \%)$ from the total of 191 data. The result also showed that need filling motive was the reason mostly chosen by 21 $(43,8 \%)$ out of 48 participants.
\end{abstract}

Keywords: Code Mixing, English Language Education Department students, Instagram

\section{INTRODUCTION}

The fourth-semester students of English Language Education Department are the students who just learned English as their second language. They have learned English for one and a half years in their college life at Ganesha University of Education. This condition makes them master not only Bahasa Indonesia, their first language, but also English as their second language. According to Wardhaugh (1992), people who master more than one language are bilinguals. Bilingualism, according to Bloomfield (as cited by Rahardi in Dewi \& Ekalaya, 2015), happens when a speaker uses two languages. Muysken (2000) states that when a speaker masters two languages, the speaker will have the habits of using those two languages when he/she is interacting with others. This habit is also experienced by the fourth semester students of ELE Department. They mix both of their languages, Bahasa Indonesia and English, when they are interacting with their friends in real life and in social media. 
When there is a mix of two languages spoken by a speaker in one sentence, code mixing happens. According to Wardhaugh (1992), code mixing occurs when a speaker uses two languages in one sentence without changing the topic. The speaker who is speaking in their native language may insert the second language that they know in their sentence. Code mixing, according to Hoffman (as cited in Dewi \& Ekalaya, 2015), is a switch from one language to another in one sentence.

Code mixing does not only occur in daily conversation. It also happens in social media networking because nowadays, people are also communicating through social media like Twitter, Facebook, and Instagram. Social media helps people to communicate, exchange information, share experiences, do discussions, and run online businesses. It helps people to communicate with each other without having to meet each other in one place. The most used platform that is used by people right now is Instagram.

Instagram is used to share pictures and videos on social networking. Instagram is available for iOS, Android, and Windows operating systems. Instagram is very addictive nowadays, especially for the students of English Language Education Department. Students of English Language Education Department open their Instagram daily. They open Instagram anytime, anywhere. Instagram is an addictive social media platform to connect with others through photos and videos. They can share their real moments, share informations, ideas, and whatever they want to Instagram.

People nowadays are not interacting in the real world only. They are also interacting through social media like Instagram, Facebook, Twitter, and other platforms of social media. But there are not many researchers who conduct the research of the code mix that happened in social media. Therefore, this research will discuss the use of code mixing on social media, especially Instagram because Instagram is the platform that is used by most of the people nowadays. The participants of this research are the fourth semester students of English Language Education Department in Ganesha University of Education because they are the active users of Instagram and they are also the bilinguals who just learned English as their second language. This research is focused on the types of code mixing used by the fourth semester students of English Language Education Department and their reason for using code mixing on Instagram.

\section{METHOD}

This research used descriptive qualitative research design to describe the analysis of code mixing used by the students of English Language Education Department on Instagram. This research concerned in analyzing the types of code mixing and the reason for using code mixing with the subject were the fourth semester students of English Language Education Department on Instagram. To analyze the types of code mixing used by the participants, this research used the combination of Hoffman, Ho, and Muysken's theory. Meanwhile, to analyze the reason for using code mixing, the combination of Hockett, Hoffman, and Saville-Troike's theory were used.

In conducting this research, there were two techniques that were used to collect the data. First, observation technique was used to collect the data of the types of code mixing used by the participants. The observation was conducted online through Instagram by observing participants' posts and comments on Instagram Feed and Instagram Story. The data which were found from the observation, were classified into the suitable types of code mixing using observation sheet, a table consist of the list of the types of code mixing from Hoffman, Ho, and Muysken's theory. Second, to collect 
the data of the reason for using code mixing, interview technique was done during this research. The interview was done online via Google Form, which asked several questions to the participants about their reasons for using code mixing on Instagram.

The procedure of data analysis that was used while conducting this research was proposed by Miles \& Huberman (1994). According to Miles \& Huberman (1994), there were four stages of qualitative data analysis. The first stage was data collection, which collected the data by observing and interviewing the subjects. The second one was data reduction which selected the collected data to be analyzed. After analyzing the data, the next step was displaying the data in the form of table and pie chart. These were used to know the percentage of each types and each reasons of the use of code mixing. Last, after knowing the percentage of the data, the last step was drawing conclusion.

\section{FINDINGS AND DISCUSSION}

\section{The Types of Code Mixing}

There were several experts who mentioned different types of code mixing. Hoffman (as cited in Dewi \& Ekalaya, 2015) states that there are three types of code mixing, namely intra-sentential code mixing, intra-lexical code mixing, and a change of pronunciation. Intra-sentential code mixing is a code mix which occurs within a phrase, clause, or sentence. Meanwhile, intra-lexical code mixing occurs within word boundary. However, a change pronunciation, as its name, it occurs in the phonological level.

Another experts, Ho (as cited in Sari et al., 2017) mentions that there are seven types of code mixing, namely letter of alphabet, short forms, proper words, lexical words, phrases, incomplete sentence, and single full sentences. From this theory, letter of alphabet, short forms, proper words, lexical words, and phrases are similar to intrasentential code mixing type by Hoffman since the words and phrases are inserted into a phrase, clause, or sentence.

However, Muysken (2000) mentions three different types of code mixing, namely insertion, alternation, and congruent lexicalization. Insertion, just like intra-sentential code mixing from Hoffman, occurs when the lexical items from one language are inserted into another. Then, alternation occurs when two languages structures are alternated at the grammatical and lexical level. Different with insertion which only inserts a word or phrase, alternation alternates clauses of both languages. Because of this, alternation is similar to incomplete sentence type from Ho since these types alternated a clause or a minor sentence of one language into a while full sentence of another language. Last, congruent lexicalization is a type of code mixing from Muysken (2000) which occurs when two languages share grammatical structure that can be filled lexically with elements from each language. At first, this type seems like the insertion type, but congruent lexicalization has more vocabulary from both of the languages in one sentence.

Those theories of the types of code mixing are typically similar to each other that make them can be combined and put into groups. The groups from the combination of those theories are intra-sentential code mixing, intra-lexical code mixing, a change of pronunciation, alternation, congruent lexicalization, and single full sentence. These groups were used to analyze the data of the types of code mixing used by the fourth semester students of English Language Education Department.

From the observation through Instagram and from the analysis result using Hoffman, Ho, and Muysken's theory about the types of code mixing used by the fourth semester students of English Language Education Department, it was found that there 
are 191 number of occurrences of code mixing on Instagram done by the participants during this research. From those 191 occurrences, intra-sentential code mixing occurred 107 times (56\%), which makes it as the most used code mixing type on Instagram by the fourth semester students of English Language Education Department. This type of code mixing did not only occur amongst the fourth semester students of English Language Education Department on Instagram. Nugraha et al., (2013) who investigated the types of code mixing used by the characters in the films written by Raditya Dika found out that most of the code mixing occurrences in the films written by Raditya Dika were the insertion of lexical words, phrases, and proper nouns. Sri et al., (2016) who discovered the types of code mixing used by the villagers in Nusa Sari village was also found that the insertion which occured within phrase, clause, or sentence was the most used code mixing used by the villagers.

After intra-sentential code mixing, the second type of code mixing that was mostly used by the participants was single full sentence type which occurred 36 times (19\%). After that, intra-lexical code mixing which occurred 17 times (9\%), congruent lexicalization which occurred 14 times (7\%), and alternation which occurred 12 times $(6 \%)$. The last, the most rarely used type of code mixing was a change of pronunciation which only occurred 5 times $(3 \%)$

\section{Reasons of Using Code Mixing}

Just like the types of code mixing, the reasons for using code mixing were also stated differently by different experts. Hockett (as cited in Hahyesalaemae, 2017) mentions two reasons for the use of code mixing, namely need filling motive and prestige filling motive. Need filling motive is a reason which appears when the speaker or the writer cannot find a word which has similar meaning with the first language. Meanwhile, prestige filling motive is a reason which appear when the speakers or writers want to show their educational or economical status by mixing their languages.

If Hockett only mentioned two reasons for using code mixing, Hoffman (as cited in Sari et al., 2017) states that there are seven reasons of the use of code mixing. The reasons are talking about particular topic, quoting somebody else, being emphatic about something, using interjection, using repetition for clarification, intending to clarify the speech content for interlocutor, and expressing group identity.

The reasons of talking about particular topic, quoting someone else, being emphatic, and interjection are similar to need filling motive by Hockett. It is because when someone is talking about particular topic, quoting someone else, being emphatic, and unintentionally uses interjection, they do not know the word in their language so they borrow the word from their second language which has the same meaning. Moreover, the reason of expressing group identity is also similar to prestige filling motive by Hockett. It is because when the speakers or writers want to express their group identity, it means that they want other people to know that they are from the certain group and they want to get the prestige from the people.

Furthermore, Saville-Troike (as cited in Dewi \& Ekalaya, 2015) states that there are three reasons for using code mixing. The reasons are soften or strengthen the request or command, real lexical need, and excluding other people. Some of these reasons for using code mixing by Saville-Troike are similar to Hockett and Hoffman's reasons. The reason of soften or strengthen the request or command is similar to prestige filling motive by Hockett. It is because if the code mixing is used to strengthen the command by giving power in the utterance, then it belongs to prestige filling motive. However, the reason of soften or strengthen the request or command is 
also similar to the reason of repetition from Hoffman. It is because sometimes people repeat what they say or what they request in other languages so that the interlocutors will understand them. Moreover, the reason of real lexical need is very similar to need filling motive by Hockett. Lack of vocabulary is a common reason for bilinguals to mix their language. They need to borrow some words from other languages in order to make their statements run smoothly, without any interruptions.

Because of those similarities, the reasons for using code mixing by Hockett, Hoffman, and Saville-Troike can be combined together. From the combination, there are five reasons for using code mixing, namely need filling motive, prestige filling motive, repetition, clarify the speech, and exclude other people. From those reasons, 21 out of 48 participants $(43.8 \%)$ chose need filling motive for their reason of using code mixing as they do not know the specific word in one language.

Saville-Troike (as cited in Dewi \& Ekalaya, 2015) says that lack of vocabulary from one language was a common reason among the bilinguals. When they did not know the word or phrase in their first language, they would change that word or phrase with something from their second language which had the same meaning. Alam (2006) in his research entitled Code-Mixing In Bangladesh: A Case Study Of Non-Government White Collar Service Holders And Professionals, said that $17 \%$ occurrence of code mixing occurred because of the lack of vocabulary. It was proven by the subject who said that sometimes they forgot the suitable words and just wrote what they remember during the interview. Another subject also said that the word "follback" which stands for "follow back" was more convenient to be used than "mengikuti balik" since it would sound ambiguous. Therefore, $43.8 \%$ of the participant used code mixing to fulfill their need filling motive.

Second reason that was chosen by most of the participants was repetition, which was chosen by 15 out of 48 participants (31.3\%). Dewi \& Ekalaya (2015) state that repeating the statement by mixing the languages was not only to clarify the statement, but also to emphasize the idea of it. Dewi \& Ekalaya (2015) and Jayanthi (2019) found out that the billinguals tended to speak in English by mentioning English quotes and proverbs, and repeated it in Bahasa Indonesia. For example, a sentence written by one of the subject on its Instagram, "I love this place karena ke tempat beginian gak bayar". It could be seen that the subject repeated the word from second language, "place", with "tempat". This repetition occurred to stress the point of their statement about the place they talked about.

The next reason is clarifying the speech which was chosen by 12 out of 48 participants (25\%). Clarifying the speech was needed in order to make the flow of the utterance or the sentence ran smoothly so it could be understood by the interlocutors or the readers. Jayanthi (2019) stated that the billinguals were triggered to clarify their speech by mixing their language. However, while the reason of repetition was also to clarify the speech, this reason of clarifying the speech had different characteristic. Repetition did the clarification by repeating the words of one language with the words in second language which had the same exact meaning and vice versa. However, Dewi \& Ekalaya (2015) stated that in the reason of clarifying the speech, the code was repeated with another code in a modified form. For example, "So cool! Emang lu bocah gokil!". In this sentence written by one of the subjects, the subject was clarifying how cool the reader was, so they explained it in Bahasa Indonesia that the reader was gokil or dope.

In the fourth place, the reason of using code mixing on Instagram was because of prestige filling motive. 7 out of 48 participants (14.6\%) said that they want to show the audiences or readiers that they know the second language so they chose this 
reason as they had prestige filling motive while communicating on Instagram. During the interview, these participants said that code mixing made them looked way more trendy, cool, and it also made the people knew that they were from English Language Education Department who master English. This is similar with a study toward Bangladesh workers by Alam (2006). The Bangladesh workers mixed their language with English to get attention from others, and after they were noticed, they would get the attention since they were talking in English. It means that English could give educated and sophisticated atmosphere for those who mixed their language with English.

The last reason as the least chosen reason of using code mixing is excluding other people. This reason was chosen only by 5 out of 48 participants $(10.4 \%)$. The purpose of excluding other people was to express one's mind to certain group only, which was the group who knew the same second language.

\section{CONCLUSION AND SUGGESTION}

There were 191 occurrences of code mixing written by the fourth semester students of English Language Education Department on their Instagram account. From 191 total of occurrences, the most used type of code mixing was intra-sentential code mixing which occurred 107 times (56\%). The second type of code mixing that was mostly used by the participants was Single Full Sentence which occurred 36 times (19\%). After that, Intra-lexical code mixing occurred 17 times (9\%), Congruent Lexicalization occurred 14 times (7\%), and Alternation occurred 12 times (6\%). The last, the most rarely used type of code mixing was A Change of Pronunciation which only occurred 5 times (3\%).

Moreover, the fourth semester students of English Language Education Department mixed their code for some reasons. From 48 responses on Google Form questionnaire, 21 participants $(43.8 \%)$ chose need filling motive as their reason for using code mixing. Then, 15 participants $(31.3 \%)$ chose repetation as their reason. After that, 12 participants (25\%) chose clarifying the speech, 7 participants $(14,6 \%)$ chose prestige filling motive, and only 5 participants $(10.4 \%)$ chose excluding other people as their reason for using code mixing on Instagram.

For other researchers who will conduct a study about code mixing, especially code mixing which occurred on Instagram or other social medias, this research was only focused on analyzing the types and the reasons of using code mixing on Instagram. Regarding with that, this research was using the combination of some theories from some experts. Therefore, other researchers also could combine other theories from other experts to have the deeper analysis of code mixing if there is any similiarites from one theory to others. Other researchers also can use this research as the reference for your research.

Meanwhile, for the students who want to learn more about code mixing, the curiosity about code mixing will be answered by reading this study. This study has explained about the types of code mixing that were used by the 4th semester students of English Language Education on their Instagram and their reasons of doing the code mixing. 


\section{REFERENCES}

Alam, S. (2006). Code Mixing in Bangladesh: A case Study of non-government whitecollar service holders and professionals. Assian Affairs, 28(4), 52-70. http://130.203.136.95/viewdoc/summary;jsessionid=C69D42EF4ED2EA95A3E16 87E8887384D?doi=10.1.1.489.9299

Dewi, C., \& Ekalaya, Y. (2015). an Analysis of Outer Code Switching and Code Mixing in. 2(1), 49-63.

Hahyesalaemae, K. (2017). Analysis of the use of Code mxing between Thai and English. 2(2), 78-83.

Jayanthi, N. N. T. (2019). An Analysis Of Code Mixing Used In Whatsapp Messenger By The Students Of English Language Education. Ganesha University of Education.

Miles, B. M., \& Huberman, M. A. (1994). Quallitative Data Analysis: An Expanded Sourcebook Second Edition. SAGE Publications.

Muysken, P. (2000). TOC and Preface. Bilingual Speech. A Typology of Code-Mixing, 1995. https://doi.org/10.1017/S153759271

Nugraha, I. K. A. W. Y., Seken, I. K., \& Agustini, D. A. E. (2013). Indonesian-English Code Mixing Used By Characters In Films Written By Raditya Dika. Jurnal Pendidikan Bahasa Inggris Undiksha, 1,1 .

https://ejournal.undiksha.ac.id/index.php/JPBI/article/view/3338

Sari, M. A. K., Suarnajaya, I. W., \& Dewi, S. K. (2017). An Analysis of Code Mixing Used in Instagram by the Students of English Language Education. Jurnal

Pendidikan Bahasa Inggris Undiksha, 5(2).

https://ejournal.undiksha.ac.id/index.php/JPBI/article/view/14930

Sri, I. G. N. P. A., Suarnajaya, I. W., \& Wedhanti, N. K. (2016). The Code-Mixing Analysis Of Nusa Penida Dialect Spoken By Nusa Sari Villagers. Jurnal Pendidikan Bahasa Inggris Undiksha., 3, 3. https://ejournal.undiksha.ac.id/index.php/JPBI/article/view/9685

Wardhaugh, R. (1992). An introduction to sociolinguistics. Great Britain: Hrtnolls Ltd, Bodmin. 